\title{
PERAN PROMOSI JABATAN TERHADAP PENINGKATAN PRODUKTIVITAS KERJA KARYAWAN (Studi pada PT. Star Comgistic Indonesia Kabupaten Sukabumi)
}

\author{
Fani Rismayanti ${ }^{1}$ \\ Faizal Mulia ${ }^{2}$ \\ Kokom Komariah ${ }^{3}$ \\ Fakultas Ilmu Administrasi dan Humaniora Universitas Muhammadiyah \\ Sukabumi, Jawa Barat, Indonesia ${ }^{1,2,3}$ \\ Email: fanirismayanti007@ummi.ac.id ${ }^{1}$, faizal_88@ummi.ac.id ${ }^{2}$, \\ ko2mpuspa@ummi.ac.id ${ }^{3}$
}

\begin{abstract}
This research was conducted at PT. Star Comgistic Indonesia Sukabumi Regency which aims to find out the role of promotion in the work productivity improvement. The samples used were as many as 90 people / respondents taken at random. Sources of data obtained were using interview techniques and questionnaires. The method used in this research is descriptive and associative by using a quantitative approach. The results of the t-test study on the promotion promotion variable showed the t-value in this study was 5.733 with a significant value of 0.000, a significant value of 0.000 was smaller than $0.05(0.000<0.05)$. So the results of this study indicate that the role of promotion in increasing work productivity has a positive and significant.
\end{abstract}

Keywords: Position Promotion; Employee Productivity.

\begin{abstract}
ABSTRAK
Penelitian ini dilakukan pada PT. Star Comgistic Indonesia Kabupaten Sukabumi yang bertujuan untuk mengetahui peran promosi jabatan terhadap peningkatan produktivitas kerja. Sampel yang digunakan yaitu sebanyak 90 orang/responden yang diambil secara acak. Sumber data yang diperoleh yaitu dengan menggunakan teknik wawancara dan penyebaran kuisioner. Metode yang digunakan pada penelitian ini yaitu deskriftif dan asosiatif dengan menggunakan pendekatan kuantitatif. Hasil penelitian uji t pada variabel promosi jabatan menunjukkan nilai t hitung pada penelitian ini sebesar 5,733 dengan nilai signifikan sebesar 0.000, nilai signifikan 0,000 lebih kecil dibandingkan dengan $0.05(0.000<0.05)$. Maka hasil penelitian ini menunjukan bahwa peran promosi jabatan terhadap peningkatan produktivitas kerja memiliki pengaruh yang positif dan signifikan.
\end{abstract}

Kata kunci: Promosi Jabatan; Produktivitas Kerja. 


\section{PENDAHULUAN}

Semakin kompleks perusahaan maka semakin membutuhkan sumber daya manusia yang baik dari segi kualitas dan kuantitasnya. Sumber daya manusia mengatur tentang tenaga kerja yang ada didalam sebuah organisasi, apabila rendahnya sumber daya manusia yang dimiliki sebuah organisasi maka akan mengalami penurunan dalam hal segi kualitas. Maka dari itu pengelolaan sumber daya manusia dalam suatu organisasi harus senantiasa dilaksanakan untuk mencapai tujuan organisasi dengan efektif dan efesien.

Peran karyawan dalam sebuah organisasi sangatlah penting, untuk menentukan keberhasilan suatu organisasi, yang telah ditetapkan oleh pemimpin dalam sebuah organisasi tersebut. Daya perangsang atau pendorong yang mendorong karyawan untuk mau bekerja dengan segiat-giatnya antara karyawan satu dengan yang lainnya yaitu disebabkan oleh perbadaan motif tujuan dan kebutuhan masing-masing karyawan. Oleh karena itu, perusahaan harus memiliki daya perangrang atau pendorong yang sangat ampuh untuk diterapkan dan lebih ditekankan.

Produktivitas kerja merupakan suatu ukuran atas penggunaan sumber daya dalam suatu organisasi yang biasanya dinyatakan sebagai rasio dari keluaran (output) yang dicapai dengan sumber daya yang digunakan namun produktivitas sangat erat kaitannya dengan efektivitas dan efesiensi (Satriadi, 2017). Dengan demikian adanya produktivitas tenaga kerja yang tinggi akan meningkatkan produktivitas perusahaan (Sari, 2018) maka dibutuhkan tegana kerja yang produktif 
dengan biaya yang seefesien mungkin sesuai dengan kondisi dan kemampuan perusahaan (John Foster Marpaung, 2014).

Produktivitas kerja dimaknai sebagai sebuah kondisi untuk mengukur tingkat kemampuan dalam mengasilkan produk, baik diukur secara individual, kelompok maupun organisai. (Kadhavi, 2019). Adapun dimensi yang dikemukakan oleh Sutrisno (2011:104) adalah sebagai berikut: 1). Kemampuan. 2). Semangat kerja. 3). Meningkatkan hasil yang dicapai. 4). Pengembangan diri. 5). Mutu. 6). Efesiensi.

Maka dimensi yang digunakan pada penelitian ini yaitu: 1) kemampuan yaitu mempunyai kemampuan kerja untuk melaksanakan tugas (Kadhavi, 2019). 2) semangat kerja merupakan usaha untuk lebih baik dari hari kemarin (Kadhavi, 2019). 3) meningkatkan hasil yang dicapai merupakan salah satu yang dapat dirasakan baik yang oleh mengerjakan maupun yang menikmati hasil pekerjaan tersebut (Kadhavi, 2019). 4) pengembangan diri yaitu senantiasa mengembangkan diri untuk meningkatkan kemampuan kerja (Kadhavi, 2019). 5) mutu yaitu selalu berusaha untuk menigkatkan mutu lebih baik dari yang telah lalu (Kadhavi, 2019). 6) efesiensi yaitu perbandingan antara hasil yang dicapai (keluaran) dengan sumber daya (masukkan) yang dipergunakan.

Promosi jabatan adalah perpindahan dari suatu jabatan ke jabatan lain yang lebih tinggi sebagai imbalan karena pretasi kerjanya yang baik, masa kerja nya lebih lama dan lain-lain. (Khotimah, 2015) dengan adanya kesempatan untuk dipromosikan maka karyawan akan termotivasi dan semangat kerjanya pun akan 
meningkat. Jika kesempatan untuk dipromosikan relative kecil atau hampir tidak ada maka gairah kerja, semangat kerja, disiplin dan prestasi kerja menurun. (Nurmansyah, 2019)

Maka penelitian ini menggunakan delapan dimensi promosi jabatan menurut Hasibuan (2013) yaitu: 1) Kejujuran 2) Disiplin 3) Prestasi kerja 4) Kerjasama 5) Kecakapan 6) Loyalitas 7) Kepemimpinan 8) Pendidikan. Dimensi ini senada dengan yang digunakan dalam penelitian (Ramadhan, Manajemen, Ekonomi, \& Bosowa, n.d.). Seperti penelitian terdahulu yang telah digunakan oleh peneliti sebelumnya, maka adanya pengaruh positif dan signifikan antara promosi jabatan terhadap produktivitas kerja (Margahana \& Sari, 2018) (Anita, 2017) (Ramadhan, 2017).

$\mathrm{H}_{1}$ : Promosi jabatan berpengaruh positif dan signifikan terhadap produktivitas kerja karyawan.

PT. Star Comgistic Indonesia (Starcom) Kabupaten Sukabumi adalah perusahaan dalam produsen alat eletronik keperluan rumah tangga seperti memproduksi alat masak eletronik, setrika listrik, teko kopi listrik, microwave oven dan alat-alat keperluan rumah tangga lainnya/home appliances.

Berdasarkan hasil wawancara dengan HRD PT. Star Comgistic Indonesia, promosi jabatan masih kurang diterapkan dan diperhatikan. Hal ini disebabkan oleh penurunan produktivitas kerja karyawan, oleh karena itu peneliti menemukan permasalahan pada produktivitas kerja yang menurun dan kurang optimal. Hal tersebut disebabkan dimana target produksi dalam 3 bulan terakhir ditahun 2019 
mengalami penurunan. Penurunan target produksi tersebut di duga disebabkan karena kurang diterapkannya promosi jabatan.

\begin{tabular}{|c|c|}
\hline Promosi Jabatan & \multirow{9}{*}{$\begin{array}{l}\text { Produktivitas Kerja } \\
\text { 1. Kemampuan } \\
\text { 2. Semangat kerja } \\
\text { 3. Meningkatkan hasil } \\
\text { yang dicapai } \\
\text { 4. Pengembangan diri } \\
\text { 5. Mutu } \\
\text { 6. Efesiensi } \\
\text { Sutrisno (2011) }\end{array}$} \\
\hline 1. Kejujuran & \\
\hline 2. Disiplin & \\
\hline $\begin{array}{l}\text { 3. Prestası kerja } \\
\text { 4. Kerjasama }\end{array}$ & \\
\hline 5. Kecakapan & \\
\hline 6. Loyalitas & \\
\hline 7. Kepemimpinan & \\
\hline 8. Pendidikan & \\
\hline Hasibuan (2013) & \\
\hline
\end{tabular}

\section{Gambar 1. Model Penelitian}

\section{METODE PENELITIAN}

Metode yang digunakan dalam penelitian ini yaitu menggunakan metode deskriftif dan asosiatif dengan menggunakan pendekatan kuantitatif. Dikatakan bahwa metode deskriptif karena pada penelitian ini mejelaskan gambaran peran promosi jabatan pada PT. Star Comgistic Indonesia Kabupaten Sukabumi. Kemudian menggunakan metode asosiatif karena dalam penelitian ini terjuan untuk mengetahui hubungan dua variabel atau lebih, selanjutnya menggunakan pendekatan kuantitatif karena pengolahan data pada penelitian ini menggunakan data statistik yang berupa angka. 
Populasi pada penelitian ini yaitu karyawan PT. Star Comgistic Indonesia Kabupaten Sukabumi. Teknik pengambilan sampel menggunakan simple random sampling. Menurut Sugiyono dalam (virginia, 2015) "Simple random sampling dikatakan (simple) artinya sederhana karena pengambilan anggota sampel dari populasi dilakukan secara acak tanpa memperhatikan starta yang ada di dalam populasi itu." Maka jumlah sampel untuk penelitian ini karyawan PT. Star Comgistic Indonesia Kabupaten Sukabumi yaitu sebanyak 90 responden. Teknik analisis data menggunakan regresi linier sederhana dan pengujian model hipotesis yaitu Uji T (parsial).

\section{HASIL DAN PEMBAHASAN}

Penelitian ini dilakukan pada karyawan PT. Star Comgistic Indonesia Kabupaten Sukabumi dengan jumlah responden sebanyak 90 orang dan hasil penelitian menunjukkan hasil pada Tabel 1 .

Tabel 1.

Hasil Regresi Linier Sederhana

\begin{tabular}{|c|c|c|c|c|c|c|}
\hline \multicolumn{7}{|c|}{ Coefficients $^{\mathrm{a}}$} \\
\hline \multirow[b]{2}{*}{ Model } & & \multicolumn{2}{|c|}{$\begin{array}{c}\text { Unstandardized } \\
\text { Coefficients }\end{array}$} & \multirow{2}{*}{$\begin{array}{c}\text { Standardized } \\
\text { Coefficients } \\
\text { Beta }\end{array}$} & \multirow[b]{2}{*}{$\mathrm{t}$} & \multirow[b]{2}{*}{ Sig. } \\
\hline & & $\mathrm{B}$ & Std. Error & & & \\
\hline 1 & (Constant) & 10,852 & 2,297 & & 4,725 & ,000 \\
\hline & $\mathrm{X}$ & ,412 & ,072 &, 521 & 5,733 & ,000 \\
\hline
\end{tabular}


Berdasarkan hasil penyebaran kuisioner yang diolah dengan menggunakan SPSS, maka dapat dihasilkan regresi linier sederhana yaitu:

$$
\begin{aligned}
& Y=a+b x \ldots \ldots \ldots \ldots \ldots \ldots \\
& Y=10.852+0.412 X
\end{aligned}
$$

Maka Persamaan tersebut dapat disimpulkan sebagai berikut : 1). Konstanta sebesar 10.852 mengandung bahwa koefesien variabel Promosi Jabatan adalah sebesar 10.852. 2). Koefisien regresi $Y$ sebesar 0.412 menyatakan bahwa setiap penambahan 1\% nilai Promosi Jabatan maka nilai Produktivitas Kerja bertambah sebesar 0.412. koefisien regresi bernilai positif sehingga dapat dikatakan bahwa pengaruh variabel $\mathrm{X}$ terhadap $\mathrm{Y}$ adalah positif.

Tabel 2.

\begin{tabular}{|c|c|c|c|c|}
\hline \multicolumn{5}{|c|}{ Model Summary } \\
\hline Model & $\mathrm{R}$ & R Square & $\begin{array}{l}\text { Adjusted R } \\
\text { Square }\end{array}$ & $\begin{array}{l}\text { Std. Error of the } \\
\text { Estimate }\end{array}$ \\
\hline 1 &, $521^{\mathrm{a}}$ & ,272 & ,264 & 1,93997 \\
\hline
\end{tabular}

\section{Hasil Koefesien Determinasi}

a. Predictors: (Constant), promosi jabatan

b. Dependen Variabel Produktivitas kerja

\section{Sumber: data diolah}

Dari hasil pada Tabel 2 diketahui nilai korelasi sebesar 0.521 dan koefisien determinasi 0.272 sehingga peran Promosi Jabatan terhadap Produktivitas kerja sebesar $27.2 \%$. maka terdapat pengaruh variabel dependent yaitu promosi jabatan terhadap variabel dependen yaitu produktivitas kerja karyawan sebesar $27 \%$ sedangkan sisanya $73 \%$ maka adanya pengaruh dari variabel lainnya. Berdasarkan hasil pada Tabel 2 maka dapat disimpulkan adanya pengarih positif dan signifikan 
pada promosi jabatan terhadap produktivitas kerja, hal ini senada dengan penelitian (Ramadhan, 2017).

Tabel 3.

Uji T (Parsial)

\begin{tabular}{|c|c|c|c|c|c|c|}
\hline \multicolumn{7}{|c|}{ Coefficients $^{a}$} \\
\hline \multirow[b]{2}{*}{ Model } & & \multicolumn{2}{|c|}{$\begin{array}{c}\text { Unstandardized } \\
\text { Coefficients }\end{array}$} & \multirow{2}{*}{$\begin{array}{c}\begin{array}{c}\text { Standardized } \\
\text { Coefficients }\end{array} \\
\text { Beta } \\
\end{array}$} & \multirow[b]{2}{*}{$\mathrm{t}$} & \multirow[b]{2}{*}{ Sig. } \\
\hline & & $\mathrm{B}$ & Std. Error & & & \\
\hline \multirow[t]{2}{*}{1} & (Constant) & 10,852 & 2,297 & & 4,725 &, 000 \\
\hline & $\begin{array}{l}\text { Promosi } \\
\text { jabatan }\end{array}$ & ,412 & 072 &, 521 & 5,733 &, 000 \\
\hline \multicolumn{7}{|c|}{ a. Dependent Variable: Produktivitas kerja } \\
\hline b. Predic & rs: (Constar & nosi jabatan & & & & \\
\hline
\end{tabular}

Sumber: data diolah

Berdasarkan Tabel 3 dapat dilihat bahwa nilai thitung dari variabel promosi jabatan (x) sebesar 5,733 dengan tingkat signifikan 0.000. nilai signifikan $0.000<$ 0.05 dan nilai koefesien regresi mempunyai sifat positif sebesar 5,733. Maka H1 diterima yang artinya ada pengaruh antara promosi jabatan (X) secara simultan terhadap produktivitas kerja (Y). Penelitian ini senada dengan penelitian yang dilakukan (Saharuddin Soehardi, 2019) dan senada dengan hasil penelitian (Sari, 2018). Dapat disimpulkan bahwa promosi jabatan berpengaruh positif dan signifikan terhadap produktivitas kerja karyawan.

\section{SIMPULAN DAN SARAN}

Berdasarkan hasil penelitian diatas menunjukkan bahwa terdapat pengaruh positif dan signifikan antara promosi jabatan $(\mathrm{X})$ terhadap produktivitas kerja 
karyawan (Y) artinya semakin baik pelaksanaan promosi jabatan akan semakin baik pula produktivitas kerja karyawan pada PT. Star Comgistic Indonesia Kabupaten Sukabumi. Dengan menggunakan teknik analisis linier sederhana dan pengujian secara parsial (uji T).

Adapun beberapa saran dalam penelitian ini yang pertama: diharapkan kepada PT. Star Comgistic Indonesia Kabupaten Sukabumi dapat terus meningkatkan dan mempertahankan produktivitas kerja karyawan, dan memberikan kesempatan untuk promosi jabatan terhadap seluruh karyawan. Sehingga karyawan semakin giat dan dalam menjalankan tugas-tugasnya dengan baik. Yang kedua: Diharapkan untuk peneliti selanjutkan dalam melakukan penelitian serupa dapat lebih mengembangkan hasil yang telah dicapai peneliti saat ini, dan bahkan lebih baik dengan menambahkan indikator-indikator yang baru.

\section{REFERENSI}

Anita, 2017. pengaruh motivasi, insentif dan promosi jabatan terhadap produktivitas kerja karyawan pada bagian penjualan pt kapuas trio tirta sari motor dikuala kapuas. 436-442.

Fahrizal, M. (2017). Pengaruh Promosi Terhadap Produktivitas Kerja Pegawai Pada Dinas Pendidikan Kabupaten Kutai Kartanegara. Jurnal Paradigma (JP), 2(2), 302-316.

Hasibuan, M. (2013). Manajemen Sumber Daya Manusia. Jakarta: PT. BUMI AKSARA.

John Foster Marpaung. (2014). Pemberian Insentif Terhadap Peningkatan Produktivitas Kerja Karyawan Pada Pt. Inited Dico Citas. 15(1), 117-122.

Kadhavi, M. 2015. (2019). studi tentang produktivitas kerja pegawai unit pelaksana tugas dinas teknologi terapan perkebunan. Journal of Chemical Information and Modeling, 53(9), 1689-1699. https://doi.org/10.1017/CBO9781107415324.004 
Khotimah, K. (2015). KERJA ( Studi pada Karyawan PT . PLN ( Persero ) Distribusi Jawa Timur Area Malang ). 25(1), 1-7.

Margahana, H., \& Sari, S. S. (2018). Analisis Promosi Jabatan Terhadap Produktivitas Kerja Karyawan Pada Pt . Fif Belitang Oku Timur. 16(1), 16.

Nurmansyah, A. (2019). Pengaruh Kebijakan Promosi Jabatan dan Insentif Terhadap Motivasi Kerja Karyawan Pada Politeknik LP3I Bandung. 8697.

Ramadhan, F. (2017). Analisis pengaruh pelatihan dan promosi jabatan terhadap produktivitas kerja karyawan pada pt semen tonasa kabupaten pangkep. 3(004), 70-86.

Saharuddin Soehardi. (2019). Pengaruh Kreativitas dan Promosi Jabatan Terhadap Peningkatan Produktivitas. 1-9.

Sari, E. (2018). the Role of Assistance and Budget Impacts in the Field of Marine and Fisheries on Welfare Conditions of Fishermen Community in Ende District. Jurnal Ekonomi Mercu Buana, 6(1), 78-102. https://doi.org/10.26486/jpsb.v6i1

Satriadi, D. (2017). Pengaruh Gaya Kepemimpinan Dan Motivasi Terhadap Produktivitas Kerja. Jurnal Benefita, 2(1), 33. https://doi.org/10.22216/jbe.v2i1.1271

Sutrisno, E. (2011). Manajemen Sumber Daya Manusia. Jakarta: Jakarta, Kencana.

virginia. (2015). Pengaruh Pelatihan, Pengalaman Kerja, Dan Promosi Jabatan Terhadap Kinerja Karyawan Pada Badan Pemeriksa Keuangan Republik Indonesia Perwakilan Sulawesi Utara. Jurnal Riset Ekonomi, Manajemen, Bisnis Dan Akuntansi, 3(3). 